\title{
Analisis Efisiensi Pemasaran Usaha Purse Seine di Kota Ambon
}

\author{
Lilian Mathilda Soukotta ${ }^{1}$ \\ Fakultas Perikanan dan IImu Kelautan \\ Universitas Pattimura, Ambon \\ Artikel Masuk : 26 Januari 2015 \\ Artikel Diterima : 13 Maret 2015
}

\begin{abstract}
Abstrak: Penelitian ini bertujuan untuk mengetahui efisiensi pemasaran dengan pendekatan struktur, perilaku dan kinerja pasar dari pemasaran hasil tangkapan purse seine di Kota Ambon.Data diperoleh dari responden yaitu nelayan pemilik purse seine dan pedagang ikan. Analisis data mencakup integrasi pasar dan elastisitas transmisi harga. Selanjutnya, analisis struktur dan perilaku pasar digunakan untuk menggambarkan kinerja pasar secara nyata yang terjadi di pasar ikan Kota Ambon. Hasil penelitian menunjukkan bahwa (1) Struktur pasar yang terjadi adalah tidak terintegrasi sempurna atau oligopsoni; (2) Perilaku pasar yaitu perilaku pedagang pengecer cenderung secara cepat menaikan harga jika harga ikan segar naik, sebaliknya agak lambat menurunkan harga jika harga ikan segar mengalami penurunan; dan (3) Pada basis lokasi pasar, jumlah pengecer lebih sedikit daripada jumlah produsen, tidak terdapat hambatan bagi produsen dan pengecer untuk keluar masuk pasar; dan ikan segar yang dipasarkan umumnya berkualitas sama kecuali pada musim ikan dimana terdapat ikan segar yang disimpan untuk dipasarkan kembali.
\end{abstract}

Kata kunci: efisiensi, struktur pasar, perilaku pasar, penampilan pasar, usaha purse seine

\begin{abstract}
The purpose of this research is to evaluate marketing efficiency by using structure, behavior, and market performance approaches of the purseseine catch in Ambon city. The data collected from the purse seine owners and fish traders cover the market integration and price transmission elasticity. The analysis of market structure and behavior are used to depicting the market performance occurred in the fish market of Ambon city. The results show that (1) market integration is absent due to oligopsony practice; (2) market behavior varies where the retailers immediately increase the fish price if the market price is sharply increasing, and they are reluctant to reduce the price if the fish price is decreasing; (3) for each market location, the number of retailersis fewer than the producers, the barriers to entry for both the producers and retailers is absent; and the fresh marketed fish has a similar quality except under the condition where the abundant fish stored in the cold storage for the next day trading.
\end{abstract}

Keywords: efficiency, market structure, market behavior, market performance, purse-seine business

\footnotetext{
${ }^{1}$ Korespondensi Penulis: Fakultas Perikanan dan Ilmu Kelautan,Universitas Pattimura

Email: ian_soukotta@yahoo.com
} 


\section{Pendahuluan}

Purse seine merupakan alat tangkap (gear) dominan menangkap ikan pelagis yang membentuk gerombolan.Alat tangkapini berbentuk empat persegi panjang dilengkapi tali kerucut yang dikerutkan melalui cincin dan diikatkan pada bagian bawah jaring. Prinsip penangkapan ikan dengan purse seine adalah melingkari gerombolan ikan dengan menggunakan jaring, kemudian bagian bawah jaring dikerucutkan sehingga ikan-ikan akan terkumpul di bagian kantong. Ikan layang (Decapterus sp) merupakan jenis ikan yang dominan tertangkap dengan purse seine, selain ikan selar (Rastrelliger $s p$ ), lemuru (Sardinella sp), dan tongkol (Auxis sp) serta jenis pelagis kecil lainnya.

Usaha perikananpurse seine di Kota Ambon terusberkembang dan pada tahun 2013 Kementerian Kelautan dan Perikanan memberikan bantuan kapal tangkap kepada kelompok nelayan di Negeri Latuhalat dan Negeri Laha Kota Ambon sebanyak 3 (tiga) armada penangkapan dengan nilai investasi sebesar Rp 1.587.475.000 (Siwalima News, 2013). Bantuan ini diberikan untuk peningkatan produksi hasil tangkapan, peningkatan pendapatan nelayan dan pemenuhan kebutuhan konsumsi masyarakat Kota Ambon.

Tercatat pada tahun 2010 terdapat 58 unit armada purse seine di Kota Ambon. Sebagian besar hasil tangkapannya dipasarkan oleh pedagang ikan di Kota Ambon. Pemasaran ikan di tingkat pedagang pengecer dilakukan oleh papalele melalui 2 (dua) bentuk saluran pemasaran sebagai berikut. Pertama nelayan $\rightarrow$ pedagang pengumpul $\rightarrow$ pedagang pengecer $\rightarrow$ konsumen. Kedua: nelayan $\rightarrow$ pedagang pengecer $\rightarrow$ konsumen. Bentuk saluran kedua memberikan bagian harga yang lebih besar kepada nelayan (Lesilolo, 2004).

Pemasaran ikan segar di Kota Ambon tidak terlepas dari masalah. Dalam berita Antara News (2012), dikemukakan bahwa pedagang di pasar Mardika dan Nusaniwe Kota Ambon mulai menjualikan beku ketika ketersediaan ikan segar menipis akibat produksi menurun. Menurut Tomek \& Robinson (dalam Lilimantik, 2011) bahwa komoditi perikanan berfluktuasi menurut jumlah produksi dan harga. Fluktuasi produksi disebabkan hasil tangkapan yang tergantung pada musim, sedangkan fluktuasi harga diakibatkan oleh pergeseran permintaan dan penawaran ikan segar di Kota Ambon. Harga ikan segar hasil tangkapan purse seine akan menentukan perilaku pasar usaha tersebut.

Efisiensi pemasaran merupakan tujuan akhir dari sistem pemasaran ikan.Pengukuran efisiensi dapat dilakukanmelalui konsep persaingan yang menghendaki penetapan kriteria meliputi aspek struktur pasar,perilaku dan penampilan pasar. Stuktur pasar dan perilaku pasar akan menentukan keragaman pasar yang dapat diukur melalui perubah harga,biaya dan marjin pemasaran serta jumlah komoditas yang diperdagangkan (Dahl \& Hammond, dalam Fransiska, 2003). Stifell \& Asmarantika (dalam Melania, 2007) juga mengukur perilaku pasar dari korelasi harga antara petani dengan harga konsumen.

Perilaku pasar yang tercermin dalam aksis suatu usaha atau pembeli dapat membantu untuk memahami pemasaran. Perilaku pasar mengacu pada pola dari tingkah laku usaha yang menunjukkan cara beradaptasi dengan pasar dimana usaha tersebut bertindak sebagai penjual dan pembeli. Perilaku dan struktur pasar usaha perikanan purse seine di Kota Ambon diindikasikan dalam penampilan pasar atau keragaman pasar. Melalui penampilan pasar, dapat diketahui seberapa jauh tingkah laku usaha di pasar memberikan kontribusi terbaik untuk dicapai sesuai dengan tujuan sosial ekonomi masyarakat.

Sejauh mana sistem pemasaran ikan segar dari hasil tangkapan purse seine berlangsung, dengan efisiensi sistem melalui sruktur, perilaku dan tingkah laku pasar merupakan permasalahan utama yang dianalisis. Dengan demikian, penelitian inipenting dilakukan untuk mengkaji efisiensi pemasaran hasil tangkapan purse seine di Kota Ambon yang memberikan gambaran mengenai mekanisme koordinasi kegiatan produksi (hasil tangkapan purse seine), distribusi dan konsumsi di Kota Ambon. 


\section{Metodologi Penelitian}

\section{Lokasi Penelitian}

Lokasi penelitian dipilih dengan purposive sampling yaitu lokasi secara sengaja ditentukan berdasarkan pertimbangan tertentu. Lokasi usaha perikanan purse seine di Kota Ambon meliputi negeri Laha, negeri Hative Besar, negeri Latuhalat, Dusun Arilow, Dusun Silale, Dusun Seri, negeri Hutumuri, dan negeri Leahari.Sedangkan pasar yang menjadi aktivitas pemasaran/penjualan adalah Pasar Tawiri, Pasar Wayame, Pasar Rumah tiga, Pasar Passo, Pasar Arumbai dan Pasar Benteng.

\section{Populasi dan Sampel}

Populasi penelitian adalah keseluruhan nelayan pemilik usaha purse seine dan pedagang yang pada umumnya memasarkan ikan layang (Decapterus sp.) dan ikan tongkol $($ Auxis $\mathrm{s} p$ ). Sebanyak 31 nelayan pemilik usaha purse seine dan 35 penjual ikan di Kota Ambon. Menurut Wahdi (2011), unsur-unsur sampel dipilih secara sengaja agar dapat memenuhi tujuan penelitian. Unsur-unsur ini dipilih untuk memperoleh informasi yang dibutuhkan.

\section{Metode Pengambilan data}

Data dikumpulkan meliputi data primer dan sekunder. Data primer diperoleh dari observasi dan wawancara langsung berdasarkan daftar pertanyaan/kuisioner dengan nelayan pemilik usaha purse seine ataupun anak buah kapal (ABK) sebagai responden. Data berkaitan dengan pemasaran diperoleh dari mereka yang bertanggung jawab dalam proses pemasaran hasil tangkapan purse seine, pedagang perantara (pembeli atau penjual hasil tangkapan purse seine). Sedangkan data sekunder diperoleh melalui instansi terkait dan bahan-bahan pustaka yang berhubungan dengan substansi penelitian.

\section{Metode Analisis Data}

Data dianalisis dengan menggunakan teknik sebagai berikut:

1. Analisis kuantitatif

a. Analisis integrasi pasar

Digunakan untuk menentukan struktur pasar dengan menggunakan analisis regresi dengan asumsi jika harga faktor lain tetap, maka harga ditingkat produsen (Pf) dan harga di tingkat konsumen (Pr) adalah linier. Model persamaannya adalah sebagai berikut (Azzaino, 1982 dalam Lilimantik, 2011):

$$
\operatorname{Pf}=\alpha+\beta \operatorname{Pr}
$$

Koefisien regresi antara Pr dan Pf adalah:

$$
\beta=\frac{\sum \operatorname{Pr} \cdot \operatorname{Pf}-\left(\sum \operatorname{Pr} \cdot \sum \mathrm{Pf}\right) / \mathrm{n}}{\left(\sum \mathrm{Pr}^{2}-\left(\sum \mathrm{Pr}^{2} / \mathrm{n}\right)\left(\sum \mathrm{Pf}^{2}-\left(\sum \mathrm{Pf}\right)^{2} / \mathrm{n}\right)\right.}
$$

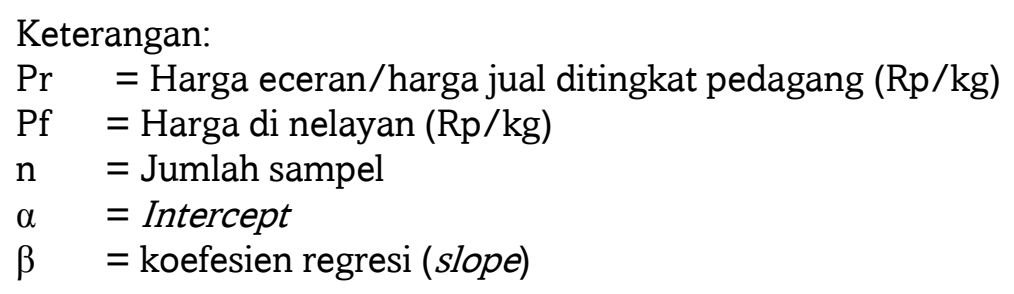


Kriteria Penilaian:

- Jika $\beta<1$, maka struktur pasarnya adalah monopsoni atau oligopsoni karena kenaikan harga satu unit ditingkat pengecer diikuti kenaikan harga yang lebih kecil dari satu unit di tingkat nelayan (produsen).

- Jika $\beta=1$, maka struktur pasarnya adalah persaingan sempurna yang berarti pembentukan harga antar pasar lebih terintegrasi ditingkat pengecer diikuti kenaikkan harga satu unit di tingkat nelayan (produsen).

- Jika $\beta>1$ maka struktur pasarnya adalah monopoli atau oligopoli karena kenaikan harga satu unit ditingka tpengecer diikuti kenaikkan harga yang lebih besar dari satu unit di tingkat nelayan (produsen).

b. Analisis elastisitas transmisi harga.

Analisis ini untuk mengetahui perilaku pasar, melalui analisis hubungan antara harga di tingkat produsen dengan harga di tingkat kosumen akhir. Elastisitas transmisi harga dirumuskan sebagai berikut (George \& King dalam Lilimantik, 2011):

$$
\eta=\beta \frac{\operatorname{Pr}}{\operatorname{Pf}}
$$

Keterangan:

$\eta \quad=$ Elastisitas transmisi harga

$\mathrm{Pr} \quad=$ Harga ditingkat kosumen $(\mathrm{Rp} / \mathrm{kg})$

$\mathrm{Pf} \quad=$ Harga ditingkat nelayan produsen $(\mathrm{Rp} / \mathrm{kg})$

Kriteriapenilaian:

- Jika $\eta<1$, artinya perubahan harga $1 \%$ ditingkat konsumen akan mengakibatkan perubahan harga yang kurang dari $1 \%$ ditingkat produsen.

- Jika $=1$, artinya perubahan harga $1 \%$ ditingkat konsumen mengakibatkan perubahan $1 \%$ ditingkat produsen.

- Jika $>1$, artinya perubahan harga $1 \%$ ditingkat konsumen mengakibatkan perubahan harga $>1 \%$ di tingkat produsen.

2. Analisis Kualitatif

Analisis kualitatif meliputi analisis struktur dan perilaku pasar yang akan menggambarkan analisis penampilan pasar dan menguraikan kondisi yang terjadi pada saat berlangsung penelitiandi lapangan.

\section{Hasil dan Pembahasan}

Berdasarkan data Dinas Kelautan dan Perikanan Kota AmbonTahun 2010, hasil tangkapan usaha purse seine didominasi oleh jenis ikan layang (Decapterus ruselli) sebesar $31,6 \%$ dan ikan tongkol (Auxis thazard) sebesar 21,8\%. Kedua jenis ikan tersebut mendominasi seluruh jenis pelagis kecil yang tertangkap dengan purse seine.

Tabel 1 dan 2 menunjukkan produksi ikan layang (Tabel 1) dan tongkol (Tabel 2) di Kota Ambon pada bulan Desember 2012 dan bulan April 2013 masing-masing $1.130 .251 \mathrm{~kg}$ dan $886.957 \mathrm{~kg}$. Produksi rata-rata sejak Desember sampai dengan April 2013 berfluktuasi dan cendrung menurun.Rata-rata produksi ikan tongkol Desember 2012 hingga April 2013 berfluktuasi dan cenderung menurun pada bulan April. Produksi tertinggi pada bulan Februari dan terendah pada bulan April. Unit usaha purse seine desa Hative Besar menghasilkan produksi tertinggi dibandingkan dengan desa lainnya. 
Tabel 1. Produksi Ikan Layang Usaha Purse Seine di Kota Ambon

\begin{tabular}{lcccccc}
\hline \multicolumn{1}{c}{ Desa (Lokasi Nelayan } & \multicolumn{5}{c}{ Produksi Ikan Layang (Kg) } \\
\cline { 2 - 7 } Pemilik Usaha Purse Seine) & Desember & Januari & Februari & Maret & April & Jumlah \\
\hline Laha & 40,322 & 34,599 & 38,697 & 29,151 & 7,448 & $\mathbf{1 5 0 , 2 1 7}$ \\
Hative Besar & 73,028 & 78,810 & 76,409 & 62,549 & 21,396 & $\mathbf{3 1 2 , 1 9 2}$ \\
Seilale dan Latuhalat & 69,109 & 69,024 & 80,747 & 62,236 & 20,839 & $\mathbf{3 0 1 , 9 5 5}$ \\
Seri & 54,123 & 59,058 & 65,981 & 49,950 & 14,400 & $\mathbf{2 4 3 , 5 1 2}$ \\
Hutumuri & 14,852 & 14,681 & 17,822 & 11,575 & 4,013 & $\mathbf{6 2 , 9 4 4}$ \\
Leaihari & 6,320 & 6,257 & 7,995 & 6,178 & 1,928 & $\mathbf{2 8 , 6 7 7}$ \\
Nusaniwe & 7,300 & 7,300 & 8,358 & 5,805 & 1,991 & $\mathbf{3 0 , 7 5 3}$ \\
Jumlah & $\mathbf{2 6 5 , 0 5 3}$ & $\mathbf{2 6 9 , 7 2 9}$ & $\mathbf{2 9 6 , 0 1 0}$ & $\mathbf{2 2 7 , 4 4 4}$ & $\mathbf{7 2 , 0 1 5}$ & $\mathbf{1 , 1 3 0 , 2 5 1}$ \\
Rataan & $\mathbf{3 7 , 8 6 5}$ & $\mathbf{3 8 , 5 3 3}$ & $\mathbf{4 2 , 2 8 7}$ & $\mathbf{3 2 , 4 9 2}$ & $\mathbf{1 0 , 2 8 8}$ & \\
\hline
\end{tabular}

Fluktuasi produksi ikan pelagis kecil menurut waktu maupun lokasi sangat berperan dalam perubahan harga ikan segar di Kota Ambon. Ini disebabkan hampir seluruh ikan segar jenis pelagis kecil di pasar Kota Ambon diperoleh dari hasil penangkapan dengan alat purse seine.

Tabel 2. Produksi Ikan Tongkol Usaha Purse Seine di Kota Ambon

\begin{tabular}{lcccccc}
\hline \multicolumn{1}{c}{ Desa (Lokasi Nelayan } & \multicolumn{5}{c}{ Produksi Ikan Tongkol (Kg) } \\
\cline { 2 - 6 } Pemilik Usaha Purse Seine) & Desember & Januari & Februari & Maret & April & Jumlah \\
\hline Laha & 27,817 & 23,869 & 26,696 & 20,111 & 5,138 & $\mathbf{1 1 8 , 6 0 3}$ \\
Hative Besar & 50,380 & 54,369 & 52,712 & 43,151 & 14,761 & $\mathbf{2 4 3 , 7 6 3}$ \\
Seilale dan Latuhalat & 47,677 & 47,618 & 55,706 & 42,935 & 14,376 & $\mathbf{2 3 6 , 8 7 0}$ \\
Seri & 37,338 & 40,742 & 45,518 & 34,459 & 9,934 & $\mathbf{1 9 2 , 5 1 8}$ \\
Hutumuri & 10,246 & 10,128 & 12,295 & 7,985 & 2,769 & $\mathbf{4 8 , 6 4 0}$ \\
Leaihari & 4,360 & 4,316 & 5,515 & 4,262 & 1,330 & $\mathbf{2 2 , 7 1 6}$ \\
Nusaniwe & 5,036 & 5,036 & 5,766 & 4,005 & 1,373 & $\mathbf{2 3 , 8 4 7}$ \\
Jumlah & $\mathbf{1 8 2 , 8 5 3}$ & $\mathbf{1 8 6 , 0 7 9}$ & $\mathbf{2 0 4 , 2 0 9}$ & $\mathbf{1 5 6 , 9 0 8}$ & $\mathbf{4 9 , 6 8 1}$ & $\mathbf{8 8 6 , 9 5 7}$ \\
Rataan & $\mathbf{2 6 , 1 2 2}$ & $\mathbf{2 6 , 5 8 3}$ & $\mathbf{2 9 , 1 7 3}$ & $\mathbf{2 2 , 4 1 5}$ & $\mathbf{7 , 0 9 7}$ & \\
\hline
\end{tabular}

\section{Pemasaran Ikan Segardi Kota Ambon}

Aspek pemasaran mencakup saluran pemasaran dan harga sebagai berikut:

1. Saluran Pemasaran

Saluran pemasaran ikan segar dari alat tangkappurse seinedi Kota Ambon melibatkan produsen, pedagang perantara, dan konsumen (Gambar 1). Produsen adalah 31 nelayan pemilik purse seinedi Kota Ambon, pedagang perantara terdiri atas 35 pedagang pengecer di 6 (enam) lokasi pasar di Kota Ambon. Konsumen adalah penduduk Kota Ambon yang mengkonsumsiikan jenis layang (Decapterus spp) dan ikan jenis tongkol (Auxis thazard). Pedagang perantara dalam saluran pemasaran ini digolongkan sebagai pedagang pengecer dikarenakan melakukan penjualan barang kepada konsumen akhir di pasar dan membeli barang dari nelayan (Hanafiah \& Saefuddin, 2006).

Keterlibatan tiga lembaga pemasaran yakni nelayan, pedagang pengecer dan konsumen menunjukkan bahwa kategori tingkat saluran pemasaran ikan segar dari purse seine di Kota Ambon merupakansaluran pemasaran tingkat satu. Artinya, produsen hanya melewati satu lembaga yaitu pedagang perantara atau pedagang pengecer. Salah satu faktor penentu saluran pemasaran adalah hasil tangkapan ikan layang dan ikan tongkol padaumumnya dipasarkan dalam bentuk segar. Ini disebabkan ikan segar merupakan produk yang mudah rusak dan akan mengalami 
penurunan mutu setelah tertangkap. Dengan demikian, ikan segar harus diterima konsumen dalam waktu singkat sehingga diperlukan saluran yang pendek dan cepat.

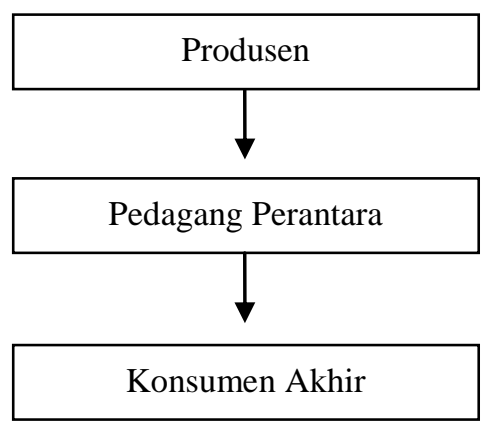

\section{Gambar 1. Saluran Pemasaran IkanSegar dari Purse Seine di Kota Ambon}

\section{Harga}

Harga rata-rata pembelian ikan tongkol dan ikan layang per loyang(yaitu Desember hingga April 2013) masing-masing adalah Rp 335.238 dan Rp 297.143. (berat 1 loyang ikan tongkol $40 \mathrm{~kg}$; dan ikan layang $30 \mathrm{~kg}$ ). Harga ikan tongkol rata-rata $\mathrm{Rp}$ $8.940 / \mathrm{kg}$, dan ikan layang Rp $8.518 / \mathrm{kg}$. Harga jual kedua jenis ikan ke konsumen yakni, Rp 15.516/kg untuk ikan tongkol (Auxis thazard) dan Rp 20.389/kg untuk ikan layang (Decapterus ruselli).

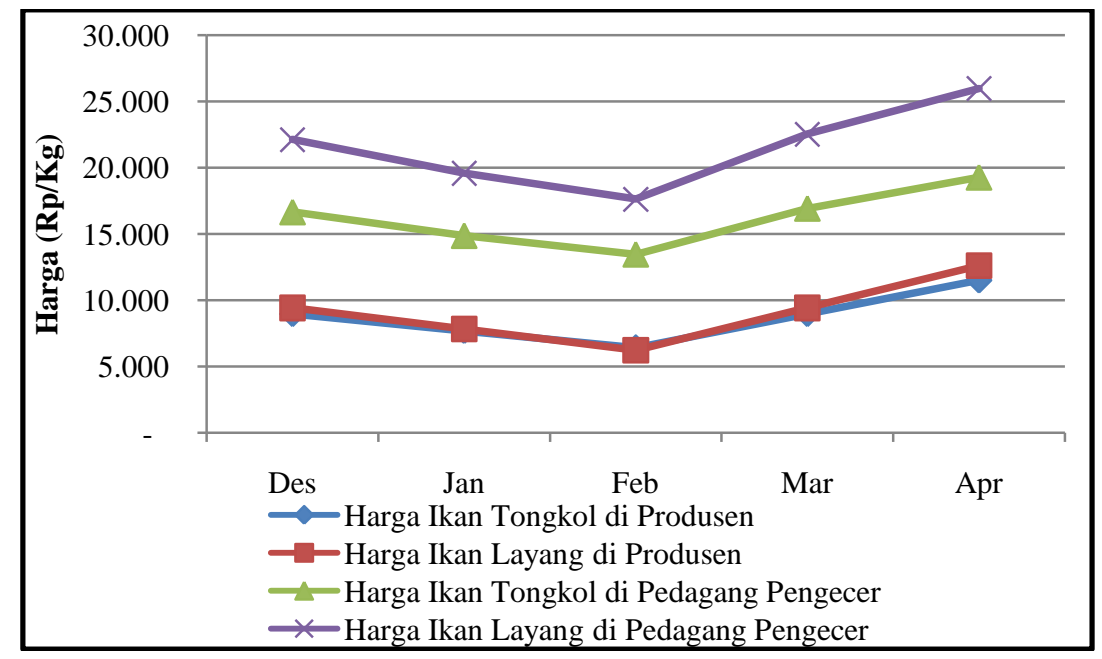

Gambar 2. Perkembangan Harga Ikan Segar Usaha Purse Seine di Kota Ambon

Perkembangan harga ikan tongkol dan ikan layang di tingkat produsen dan pedagang pengecer ditampilkan pada Gambar 2. Harga kedua jenis ikan berfluktuasi dari bulan Desember 2012 hingga bulan April tahun 2013. Fluktuasi harga dipengaruhi oleh volume produksi ikan yang dipasok ke pasar, yang ditentukan musim ikan. Harga ikan terendah terjadi pada bulan Februari dan tertinggi pada bulan April. Ini sejalan perubahan produksi ikan pada Tabel 1 dan 2, yaitu produksi ikan dari purse seine tertinggi pada pada bulan Februari. 


\section{Struktur Pasar}

Struktur pasar dan perubahan harga di tingkat produsen dengan harga di tingkat pengecer dipahami melalui integrasi pasar. Tabel 3 menunjukkan hasil analisis regresi harga ikan di tingkat produsen dan pengecer dan menunjukkan model untuk menggambarkan hubungan antara harga di tingkat produsen (Pf) dan harga di tingkat pengecer (Pr). Model untuk menggambarkan hubungan antara harga di tingkat produsen (Pf) dan harga di tingkat pengecer (Pr) pemasaran ikan segar dari purse seine di Kota Ambon adalah Pf $=5.480,29+0.185$ Pr. Model ini dapat memprediksi dengan baik pengaruh antara harga di tingkat pedagang pengecer terhadap harga di tingkat produsen (nelayan purse seine) karena nilai $F_{\text {hitung }}(47,465)$ yang memiliki nilai signifikan pada taraf kepercayaan 99\%. Artinya perubahan harga ikan di tingkat pengecer berpengaruh nyata terhadap harga di tingkat produsen.Pengaruh positif pada koefisien regresi mengindikasikan naiknya harga ikan hasil tangkapan usaha purse seine ditingkat pengecer akan diikuti dengan naiknya harga ikan di tingkat produsen.

Tabel 3. Hasil Analisis Regresi Harga Ikan di Tingkat Produsen dan Tingkat Pengecer

\begin{tabular}{llcc}
\hline No. & \multicolumn{1}{c}{ Parameter Regresi } & Nilai & Tingkat Signifikan \\
\hline 1. & $\mathrm{R}$ (korelasi) & 0,768 & - \\
2. & $\mathrm{R}^{2}$ (determinasi) & 0,590 & - \\
3. & $\alpha$ (intercept $)$ & $5.480,29$ & 0,000 \\
4. & $\beta$ (slope) & 0,185 & 0,002 \\
5. & $\mathrm{~F}_{\text {hitung }}$ & 47,465 & 0,000 \\
\hline
\end{tabular}

Perubahan harga di tingkat pengecer dan produsen terlihat pada nilai koefesien regresi slope $(\beta)$ sebesar 0,185 . Nilai ini lebih kecil dari satu $(\beta<1)$, artinya kenaikan harga Rp 1,00 di tingkat pengecer diikuti kenaikan harga Rp 0,185 di tingkat produsen. Perbedaan besaran kenaikan harga (dimana ditingkat pengecer lebih dari di tingkat produsen) mengindikasikan struktur pasar ikan dari purse seine di Kota Ambon bersifat tidak terintegrasi sempurna atau struktur pasar adalah oligopsoni karena kenaikan harga satu unit ditingkat pengecer diikuti kenaikan harga yang lebih kecil di tingkat produsen (nelayan produsen ikan dari purse seine).

Kenaikan harga di tingkat pengecer lebih besar dari harga di tingkat produsen, disebabkan oleh tingginya biaya pemasaran yang ditanggung oleh pengecer. Ini terjadi karena pengecer berupaya memperoleh keuntungan dalam penjualan ikan hasil tangkapan purse seine di Kota Ambon. Jarak antara tempat pendaratan ikan oleh armada purse seine dan pasar yang tersebar di wilayah Kota Ambon cenderung menimbulkan biaya transportasi yang ditanggung pengecer dalam akibat penggunaan sarana transportasi. Hasil riset menunjukkan pengecer mengalokasikan biaya transportasi tiap aktivitas penjualan sebesar $\mathrm{Rp}$ 5.000. Selain itu, biaya konsumsi dan retribusi tempat berjualan juga dikeluarkan oleh pengecer. Dengan demikian, penentuan harga jual ikan pada tingkat pengecer disesuaikan dengan biaya yang dikorbankan oleh pengecer. Menurut Mulyadi (2001), pada prinsipnya harga jual harus dapat menutupi biaya penuh ditambah dengan profit yang wajar. Artinya harga jual sama dengan biaya produksi ditambah mark-up. Efisiensi harga dapat diukur melalui korelasi harga untuk komoditi yang sama pada berbagai tingkat pasar.

Berdasarkan distribusi pedagang pengecer dengan jumlah relatif sedikit pada lokasilokasi pemasaran ikan, diduga terdapat praktek oligopsoni dalam pemasaran ikan segar dari purse seine. Menurut Hanafiah \& Saefuddin (2006), pada pasar oligopsoni terdapat pihak pembeli benda tertentu dalam jumlah sedikit. Misalnya, terdapat lima pedagang 
pengecer di Pasar Wayame, tiga pengecer di pasar Passo, dua pengecer masing-masing di Pasar Arumbai dan Pasar Rumah Tiga. Jumlah pedagang pengecer yang tidak tersebar secara merata di masing-masing pasar (enam pasar) mengakibatkan ada sebagian pasar hanya terdapat 2-5 pedagang pengecer yang menjual/memasarkan hasil tangkapan usaha purse seine.

Kepekaan perubahan harga di tingkat produsen sebagai akibat perubahan harga di tingkat konsumen dilakukan melalui analisis Elastisitas Transmisi Harga, sekaligus penentuan efisiensi harga adalah tercantum pada Tabel 4. Nilai elastisitas transmisi harga antara harga di tingkat produsen dengan harga di tingkat pengecer adalah kurang dari satu $(\eta<1)$, yaitu sebesar 0,383 . Nilai tersebut mengindikasikan bila terjadi perubahan harga sebesar $1 \%$ di tingkat pedagang pengecer maka terjadi perubahan harga sebesar $0,383 \%$ di tingkat nelayan purse seine sebagai produsen. Menurut Sudiyono (2004), elastisitas transmisi harga (Et) merupakan perbandingan perubahan nisbi harga di tingkat pengecer dengan perubahan harga di tingkat produsen. Yuniarti (2009) menjelaskan bahwa, elastisitas transmisi harga untuk hasil-hasil pertanian umumnya bernilai kurang dari satu $(\eta<1)$. Hal ini menunjukan bahwa laju perubahan harga di tingkat produsen lebih kecil daripada laju perubahan harga di tingkat pengecer dan pasar berbentuk persaingan tidak sempurna. Kondisi ini dapat terjadi akibat kurangnya informasi harga di tingkat produsen sehingga lebih menguntungkan pengecer karena keputusan menaikan harga ditentukan pengecer, sedangkan produsen hanya sebagai penerima harga yang lemah dalam pembentukan harga. Tabel 4 memperlihatkan rasio harga dan nilai elastisitas transmisi harga ikan segar hasil tangkapan purse seine di kota Ambon.

Tabel 4. Rasio Harga dan Nilai Elastisitas Transmisi Harga

\begin{tabular}{llc}
\hline No. & \multicolumn{1}{c}{ Koefisien } & Nilai \\
\hline 1. & Pf & Rp 8.871 \\
2. & $\mathrm{Pr}$ & $\mathrm{Rp} 18.370$ \\
3. & $\mathrm{Pr} / \mathrm{Pf}$ & 2,071 \\
4. & $\beta($ slope $)$ & 0.185 \\
5. & $\eta$ & 0,383 \\
\hline
\end{tabular}

Nilai elastisitas transmisi harga kurang dari satu menunjukkan ikan segar hasil tangkapan usaha purse seine bersifat inelastis. Artinya perubahan harga di tingkat pengecer tidak dapat ditransmisikan secara sempurna sampai ke tingkat nelayan purse seine di Kota Ambon.

\section{Perilaku Pasar pada Pasar Ikan di Kota Ambon}

Perilaku pasar yang dimaksud dalam kajian ini adalah pola tingkah laku dari lembaga pemasaran ikan yang menyesuaikan dengan struktur pasar dimana lembaga pemasaran melakukan kegiatan pembelian dan penjualan. Ini dapat dilihat dari proses pembentukan harga dan stabilitas harga serta ada tidaknya praktek jujur dari lembaga pemasaran yang terlibat. Soekartawi (2002) menjelaskan bahwa perilaku pasar (market conduct) merupakan gambaran tingkah laku lembaga pemasaran dalam menghadapi struktur pasar untuk tujuan mendapatkan keuntungan sebesar-besarnya yang meliputi kegiatan pembelian, penjualan, penentuan harga serta siasat pasar seperti patokan harga, penimbangan curang dan lainlain.

Pembelian ikan segar biasanya dilakukan pengecer yang selalu membeli langsung dari produsen atau pemilik alat tangkap purse seine. Kemudian, para pedagang akan memperhitungkan seluruh biaya yang telah dikeluarkan ditambah keuntungan untuk 
penentuan harga ikan di tingkat pengecer. Berbagai siasat dilakukan pedagang dalam penentuan harga ikan biasanya tidak diketahui oleh produsen karena pedagang perantara/pengecer menanggung seluruh biaya pemasaran seperti seperti biaya transpor, es, retribusi dan biaya lainnya. Kondisi ini terjadi akibat tidak tersedianya tempat pelelangan ikan sehingga pedagang secara bebas menentukan harga ikan segar hasil tangkapan purse seine. Hal lain yang juga mendorong pengecer yaitu secara cepat menaikan harga ikan jika harga ikan segar di tingkat nelayan pemilik purse seine meningkat. Namun, pengecer sangat lambat menurunkan harga apabila harga ikan segar di tingkat nelayan pemilik purse seine di Kota Ambon mengalami penurunan.

Perilaku pedagang pengecer teridentifikasi dipengaruhi oleh biaya yang harus dikeluarkan dalam pemasaran ikan segar di Kota Ambon. Misalnya, pada saat harga ikan segar di tingkat produsen meningkat, sebagian pedagang/pengecer mengalami kesulitan untuk memperoleh modal atau biaya untuk membeli ikan segar dari produsen.

Perilaku penentuan harga ikan segar yang berfluktuasi dalam jangka pendek di tingkat produsen terjadi karena sifat produk ikan segar sangat tergantung pada musim, sehinggajumlah produksi relatif tidak stabil. Jika jumlah produksi (hasil tangkapan ikan tongkol dan ikan layang) meningkat maka harga ditingkat produsen relatif stabil. Sebaliknya, jika terjadi penurunan produksi maka harga ditingkat produsen meningkat, dimana produsen berupaya memperoleh keuntungan ataupun menutupi biaya operasional yang dikeluarkan selama melakukan aktivitas penangkapan. Hanafiah \& Saefuddin (2006) mengemukaka nbahwa kebanyakan harga produk perikanan berfluktuasi secara musiman. Perubahan harga ini terjadi karena perubahan produksi, dan harga musiman ikan segar bervariasi lebih besar dibandingkan dengan harga ikan olahan.

\section{Penampilan Pasar Produksi Ikan Purse Seine}

Penampilan atau keragaan pasar produksi ikan merupakan kondisi yang sering diukur dengan kriteria antara lain: (1) kemajuan teknologi, (2)orientasi untuk perkembangan dari lembaga-lembaga pemasaran, (3) efisiensi penggunaan sumber, dan (4) perbaikan produk danmaksimisasi jasa-jasa dengan biaya serendah-rendahnya. Menurut Lilimantik (2011) terdapat empat karakteristik pasar yang penting dikembangkan dalam penentuan struktur pasar dan perilaku pasar.

1. Jumlah besar penjual dan pembeli

Berdasarkan hasil penelitian diketahui bahwa jumlah produsen (nelayan pemilik usaha purse seine) lebih sedikit dari jumlah pedagang pengecer.Walaupun secara keseluruhan jumlah pedagang pengecer lebih banyak dari produsen, namun jika dikaji masing-masing lokasi pasar, maka jumlah pedagang pengecer lebih sedikit dibandingkan dengan jumlah produsen. Hal ini memungkinkan pedagang pengecer untuk dapat berpindah dalam aktivitas pembelian ikan segar dari produsen lain, jika tidak menemukan kesepakatan harga dengan produsen sebelumnya.

2. Sifat hasil produk

Ikan segar (ikan tongkol dan layang) di tingkat produsen (nelayan pemilik purse seine) memiliki kulitas yang relatif sama, kecuali pada musim ikan. Pada musim ikan, identik dengan berlimpahnya ikan hasil tangkapan. Jika ikan tidak habis terjual,maka disimpan dan selanjutnya di jual kembali pada hari berikutnya. Oleh sebab itu kualitasnya tidak seragam dibanding kualitas sebelumnya. Sebelum dijual ke pedagang pengecer, maka fungsi standarisasi dan grading dilakukan oleh produsen. Ikan segar yang tertangkap di kelompokan menurut kualitas dan ukuran ke dalam wadah (loyang, ember atau bakul) kemudian dijual kepada pedagang pengecer.

3. Hambatan keluar masuk pasar

Produsen maupun pedagang pengecer tidak dibatasi secara langsung karena tidak ada peraturan resmi untuk menghalangi produsen maupun pedagang pengecer untuk 


\section{Analisis Efisiensi Pemasaran Usaha Purse Seine di Kota Ambon}

menjalankan fungsi pembelian dan penjualan. Misalnya sistem lelang yang ditetapkan oleh produsen seperti di Dusun Silale, dan Desa Latuhalat, yang memungkinkan berbagai pedagang pengecer untuk dapat menjalankan fungsi pembelian. Namun sebagian besar produsen telah memiliki pelanggan dengan pengecer. Kerja sama ini telah terbentuk sejak lama hingga terbentuk suatu ikatan sehingga tidak mudah bagi produsen untuk menjual kepada pedagang pengecer lain yang bukan langganannya. Jadi secara alami terbentuk segmentasi pasar untuk masing-masing produsen dan pedagang pengecer.

4. Pengetahuan tentang harga dan struktur biaya

Perkembangan harga ikan segaryang terjadi sebenarnya merupakan perkembangan harga yang selalu terkait dengan harga-harga sebelumnya, seperti biaya produksi di tingkat produsen, dan biaya pemasaran di tingkat pedagang pengecer, ataupun perkembangan harga bahan kebutuhan secara keseluruhan (harga barang lainnya di pasar). Oleh sebab itu, perubahan harga yang terjadi bukanlah karena tersedia atau kurangnya informasi yang memadai sehingga memungkinkan para pedagang pengecer ataupun produsen melakukan diskriminasi harga yang menyebabkan harga di tingkat konsumen menjadi tinggi.

Biaya produksi di tingkat produsen, terkait dengan biaya operasional kegiatan penangkapan (biaya variabel) maupun biaya perawatan dan retribusi/pajak (biaya tetap). Biaya tersebutakan diperhitungkan dan disesuaikan dengan jumlah produksi untuk menentukan harga jual. Sedangkan di tingkat pedagang pengecer, biaya pemasaran mencakup: biaya pembelian ikan segar, biaya trasnportasi/distribusi, biaya konsumsi, biaya pembelian es, biaya retribusi/pajak tempat berjualan menjadi pertimbangan dalam penentuan harga jual ikan segar kepada konsumen.

\section{Kesimpulan dan Saran}

\section{Kesimpulan}

Berdasarkan hasil dan pembahasan, maka dapat disimpulkan sebagai berikut:

1. Struktur pasar ikan produksipurse seine di Kota Ambon adalah pasar yang tidak terintegrasi sempurna atau struktur pasar bersifat oligopsoni.

2. Perilaku pasar tercermin dari perilaku pedagang pengecer yang cepat menaikan harga jika harga ikan segar di tingkat nelayan usaha purse seine meningkat, namun akan lebih lambat menurunkan harga jika harga ikan segar di tingkat produsen (nelayan usaha purse seine di Kota Ambon) menurun.

3. Penampilan pasar dari produksipurse seine menunjukkan bahwa walaupun secara keseluruhan jumlah pedagang pengecer lebih banyak dari produsen, namun jika dilihat dari masing-masing lokasi pasar, maka jumlah pedagang pengecer lebih sedikit dibandingkan dengan jumlah produsen; kemudian produsen dan pedagang pengecer ini tidak memiliki hambatan untuk keluar masuk pasar, serta ikan segar yang dipasarkan memiliki kualitas relatif sama, kecuali kualitas hanya pada musim ikan.

Saran

Dibutuhkan kepedulian instansi terkait terhadap sarana penyimpanan beku pada lokasi pasar maupun tempat pelelangan ikan untuk menghambat fluktuasi harga ikan produksi ikan tidak menentu. 


\section{Daftar Pustaka}

Antara News. (2012). Stok ikan segar di Kota Ambon kosong. Retrieved from http://ambon.anatranews.com. Diunduh tanggal 13 september 2012.

Bacuks L.. (2006). Marketing margins and price transmission on the Hungarian beef market. Retrieved from www.google sholar/Price Transmission.com.

Dinas Kelautan dan Perikanan Provinsi Maluku. (2010). Laporan tahunan statistik kelautan dan perikanan Provinsi Maluku tahun 2010. Maluku: Dinas Kelautan dan Perikanan, Provinsi Maluku.

Fransiska, A. (2003). Analisis efisiensi pemasaran ikan kembung (Studi kasus Muara Angke, Kecamatan Penjaringan, Kotamadya Jakarta Utara, Provinsi DKI Jakarta) (Unpublished undergraduate thesis). Jurusan Ilmu-Ilmu Sosial Ekonomi Pertanian Fakultas Pertanian Institut Pertanian Bogor, Bogor.

Hanafiah, A. M., \& Saefuddin. A. M. (2006). Tataniaga hasil perikanan. Jakarta: Penerbit Universitas Indonesia.

Lesilolo, J. (2004). Analisis marjan pemasaran ikan laut segar di Kota Ambon (Unpublished master's thesis). Program Studi Magister Manajeman Agribisnis Universitas Gadjah Mada, Yogyakarta.

Lilimantik, E. (2011). Struktur, perilaku dan penampilan pasar usaha budidaya ikan mas (Cyprinus carpio) dalam karamba di Kabupaten Banjar Provinsi Kalimantan Selatan. J-PAL, 1(2), 103-108.

Melania. (2007). Struktur, perilaku dan keragaan pasar. Jurnal Eksekutif, 4(3), 424-433.

Mulyadi. (2001). Akuntansi manajemen konsep, manfaat dan rekayasa (edisi ketiga). Jakarta: Penerbit Salemba Empat.

Siwalimanews. (2013). KKP berikan bantuan kapal bagi nelayan Latuhalat dan Laha. Retrieved from http://www.siwalimanews.com/.

Soekartawi. (2002). Agribisnis teori dan aplikasinya. Jakarta: Raja Grafindo Persada.

Sudiyono, A. (2004). Pemasaran pertanian. Malang: Universitas Muhamadiyah Malang.

Wahdi, M. (2011). Riset pemasaran. Yogyakarta: Penerbit.CAPS.

Yuniarti, T. (2009). Efisiensi pemasaran jambu mete di Kabupaten Lombok Barat. Wacana, 12(1), 204-216. 
26 Analisis Efisiensi Pemasaran Usaha Purse Seine di Kota Ambon

JURNAL WILAYAH DAN LINGKUNGAN, 3(1), 15-26 